\title{
SEED YIELD AND YIELD COMPONENTS OF SESAME AS AFFECTED BY VARIOUS WEED CONTROL METHODS
}

\author{
J. Hossain ${ }^{1}$, M.O. Ali ${ }^{2}$, M.A. Islam ${ }^{1}$, M.S. Alam ${ }^{1}$, M.R. Islam ${ }^{3}$ and J. Rahman ${ }^{3}$ \\ ${ }^{1}$ Pulses Research Centre, ${ }^{2}$ Pulses Research Sub-station, ${ }^{3}$ Regional Agricultural Research Station, Bangladesh \\ Agricultural Research Institute (BARI), Bangladesh \\ Corresponding E-mail: jamilbari11@gmail.com
}

(Received: 27 April 2020, Accepted: 04 August 2020)

Keywords: Panida 33 EC, sesame, yield, weed control method, weed biomass

\begin{abstract}
Weed control strategy greatly influences on weed infestation and yield of sesame. An experiment was conducted at Regional Agricultural Research Station, Ishurdi, Pabna during Kharif-1 season of two consecutive years 2015-16 and 2016-17 to find out the suitable weed control methods in sesame. It comprises five weed control methods viz., Application of Panida $\left(\mathrm{T}_{1}\right)$, Application of Panida with one hand weeding at $20 \mathrm{DAE}\left(\mathrm{T}_{2}\right)$, One hand weeding at $20 \mathrm{DAE}\left(\mathrm{T}_{3}\right)$, Two hand weedings at 20 and $40 \mathrm{DAE}\left(\mathrm{T}_{4}\right)$ and Control (no weeding) $\left(\mathrm{T}_{5}\right)$. The experiment was laid out in a randomized complete block design with three replications. Among the weed species, Cyperus rotundus and Digitaria sangunalis were the most abundant weeds. Application of Panida with one hand weeding at $20 \mathrm{DAE}\left(\mathrm{T}_{2}\right)$ gave the lowest weed density, weed biomass and the highest weed control efficiency followed by application of Panida $\left(T_{1}\right)$ in both years. Weed biomass influenced negatively on plant height, number of capsule plant ${ }^{-1}$, seed yield and stalk yield. The maximum seed yield and stalk yield were also obtained from $T_{2}$ which was statistically similar to $T_{1}$ treatment and the minimum seed yield from $T_{5}$. Economic analysis indicated that $\mathrm{T}_{2}$ gave higher gross return but $\mathrm{T}_{1}$ provided higher gross margin and benefit cost ratio. The treatment, $\mathrm{T}_{4}$ showed higher total variable cost due to the high cost of labour for hand weeding with the increase of variable cost, which affected the marginal return and benefit-cost ratio. However, based on the economic point of view, application of Panida in pre-emergence condition $\left(T_{1}\right)$ was a profitable and suitable weed control method in summer sown sesame.
\end{abstract}

\section{Introduction}

Sesame [Sesamum indicum (L.)] is one of the important edible oilseeds cultivated crop in Bangladesh. It's oil content generally varies from 46 to $52 \%$ and protein content between 20$26 \%$. The production of this crop is 35000 metric tons from 93000 acres of land in Bangladesh (BBS, 2019). It is cultivated almost everywhere in the country in the early summer (Kharif-1) under rain fed condition. Severe weed competition is one of the major constraints of low yield of sesame. Prevalence of high temperature with high relative humidity and frequent rainfall during the crop season leads to become wet and moist soil which is favorable for flourishing weed growth and slower plant growth, particularly during early growth stages. A critical period of weed competition in sesame is between 15 and 30 days after seedlings emergence and weeds alone reduce about 50-78\% seed yield of sesame (Karnas et al., 2019; Amare et al., 2011). Besides, the rising cost of labour and difficulty of mechanical weeding due to moist soil condition in the summer season call for an alternate weed control measure (Punia et al., 2001). 
Though manual weeding is effective and eco-friendly yet they are tedious and time-consuming. However, chemical weed management is more favourable and effective as they are quick in action, selective in nature, cost effective and efficient to control weeds during the critical period (Jain et al., 2001; Jain and Badkul, 2013). Many herbicides are presently used for controlling weeds in rice field. But the information about the weed control methods in summer sown sesame is meager. Therefore, the present experiment has been undertaken to find out the appropriate weed control methods for summer sesame.

\section{Materials and Methods}

\section{Location, soil and climatic condition}

The present study was carried out at the Regional Agricultural Research Station, Ishurdi, Pabna during two consecutive years, 2016 and 2017 (Kharif-1 season), geographical position: 24.11 ${ }^{\circ}$ N; 89.07 $\mathrm{E}$; under the AEZ-11 (High Ganges River Flood plain) (FRG, 2012). The soil of the experimental site was medium-high and clay loam texture having $1.22 \%$ organic matter, $\mathrm{pH}$ $7.40,0.07 \%$ total nitrogen $(\mathrm{N}), 0.36 \mathrm{meq} 100 \mathrm{~g}^{-1}$ soil potassium $(\mathrm{K}), 10.6 \mathrm{ppm}$ phosphorus $(\mathrm{P})$, $7.2 \mathrm{ppm}$ sulfur (S) and $1.13 \mathrm{ppm}$ zinc $(\mathrm{Zn})$. It is under sub-tropical humid climatic conditions and the detailed daily maximum, minimum temperature and rainfall were presented in Fig. 1 and Fig. 2. The average daily minimum and maximum temperatures were $23.49^{\circ} \mathrm{C}$ and $33.49^{\circ} \mathrm{C}$ in the first year, respectively and $24.57{ }^{\circ} \mathrm{C}$ and $34.04{ }^{\circ} \mathrm{C}$ in the second year during the growing period (March-July). However, the differences in minimum and maximum temperatures were slightly less in the first season than the second season. The total rainfall (March-July) was $1221 \mathrm{~mm}$ in 2016 and $4768 \mathrm{~mm}$ in 2017, which was higher than first season.

\section{Treatments and design}

The experiment was laid out in a randomized complete block design (RCBD) with 3 replications. The unit plot size was $3 \mathrm{~m} \times 4 \mathrm{~m}$. Five weed control methods were included in this study. These were application of Panida $\left(\mathrm{T}_{1}\right)$, application of Panida with one hand weeding at $20 \mathrm{DAE}\left(\mathrm{T}_{2}\right)$, one hand weeding at $20 \mathrm{DAE}\left(\mathrm{T}_{3}\right)$, Two hand weedings at 20 and $40 \mathrm{DAE}\left(\mathrm{T}_{4}\right)$ and Control (no weeding) ( $\left.T_{5}\right)$. Herbicide, Panida 33 EC (Pendimethalin, $2.5 \mathrm{~L} \mathrm{ha}^{-1}$ ) was applied as a preemergence condition at moist soil condition just after post sowing irrigation for proper seed germination. Spraying was done at the rate of $5 \mathrm{~mL}$ Panida per liter water with Knapsack charger hand sprayer fitted with T-Jet nozzle.

\section{Field experiment}

Sesame var. BARI Til-4 was used in the experiment. Seeds were sown on 10 April and 14 March, 2016 and 2017 respectively in line by hand maintaining $30 \mathrm{~cm}$ rows with continuous seeding. Fertilizer was applied @ 58-25-40-20-2-1 kg ha-1 of N-P-K-S-Zn-B respectively in the form of urea, triple superphosphate, muriate of potash, gypsum, zinc sulphate and boric acid, respectively (FRG, 2012). Half of $\mathrm{N}$ and all other fertilizers were applied at final land preparation and the remaining $\mathrm{N}$ was applied as top-dressed at 25 days after emergence. Tilt $250 \mathrm{EC}$ (Propiconazole) and Nitro [Chlorpyrifos (50\%) + Cypermathrin (5\%)] were sprayed at after flowering to control diseases and insects. No irrigation was applied and weeding was done as per treatments. The crop was harvested on 11 July and 14 June, 2016 and 2017 respectively.

\section{Data collection}

Species wise weed population was counted at random from an area of one $1 \mathrm{~m}^{2}$ per each plot with quadrate $(1 \mathrm{~m} \times 1 \mathrm{~m})$ at $30 \mathrm{DAE}$ (days after emergence) and the dry weight of weed species was determined after in an oven-drying for 72 hours at $70^{\circ} \mathrm{C}$. The weight of the dried samples was taken and the average data were expressed as weed biomass $\left(\mathrm{g} \mathrm{m}^{-2}\right)$. The frequency of 
different weeds was determined and the density of each species was calculated according to Odum (1971).

Weed density $\left(\right.$ no. $\left.\mathrm{m}^{-2}\right)=\frac{\text { Total number of weeds }}{\text { Total survey areas }\left(\mathrm{m}^{-2}\right)}$

Relative weed density $=\frac{\text { Density of each weed species }}{\text { Total density of all weed species }} \times 100$

Weed control efficiency (WCE) was calculated according to the formulae of Mani et al. (1973).

WCE $(\%)=\frac{\text { Dry weight in weedy check plot - dry weight in treatment plot }}{} \times 100$

Dry weight in weedy check plot

Weed persistence index (WPI) was computed using the given formula as suggested by Mishra and Mishra (1997)

WPI $=\frac{\text { Weed population in control plot }}{\text { Weed population in treated plot }} \times \frac{\text { Weed dry weight in treated plot }}{\text { Weed dry weight in control plot }}$

Five plants of sesame in each plot were selected randomly to gather data on yield components. Data on plant population $\mathrm{m}^{-2}$ of sesame were recorded at physiological maturity and the crop was harvested plot-wise at full maturity. The harvested crop was bundled separately with tag and then brought to the threshing floor. Yield and yield components were recorded after harvesting the crop. Seed and stalk were dried in the sun to minimize the moisture and converted to yield $\left(\mathrm{kg} \mathrm{ha}^{-1}\right)$. Data were recorded on plant height $(\mathrm{cm})$, branches plant ${ }^{-1}$ (no.), capsules plant ${ }^{-1}$ (no.), capsule length $(\mathrm{cm})$, seeds capsule ${ }^{-1}$ (no.), 1000-seed weight $(\mathrm{g})$, seed yield ( $\mathrm{kg} \mathrm{ha}^{-1}$ ) and stalk yield $\left(\mathrm{kg} \mathrm{ha}^{-1}\right)$.

\section{Statistical Analysis}

The analysis of variance (ANOVA) of collected data were performed statistically using ' $R$ ' software (version: R-3.3.1) ( $\mathrm{R}$ Core Team, 2016) and mean separation was done as least significant difference (LSD) at 5\% level of significance (Gomez and Gomez, 1984). Yield and yield components of sesame did not vary year to year so pooled analysis was done.

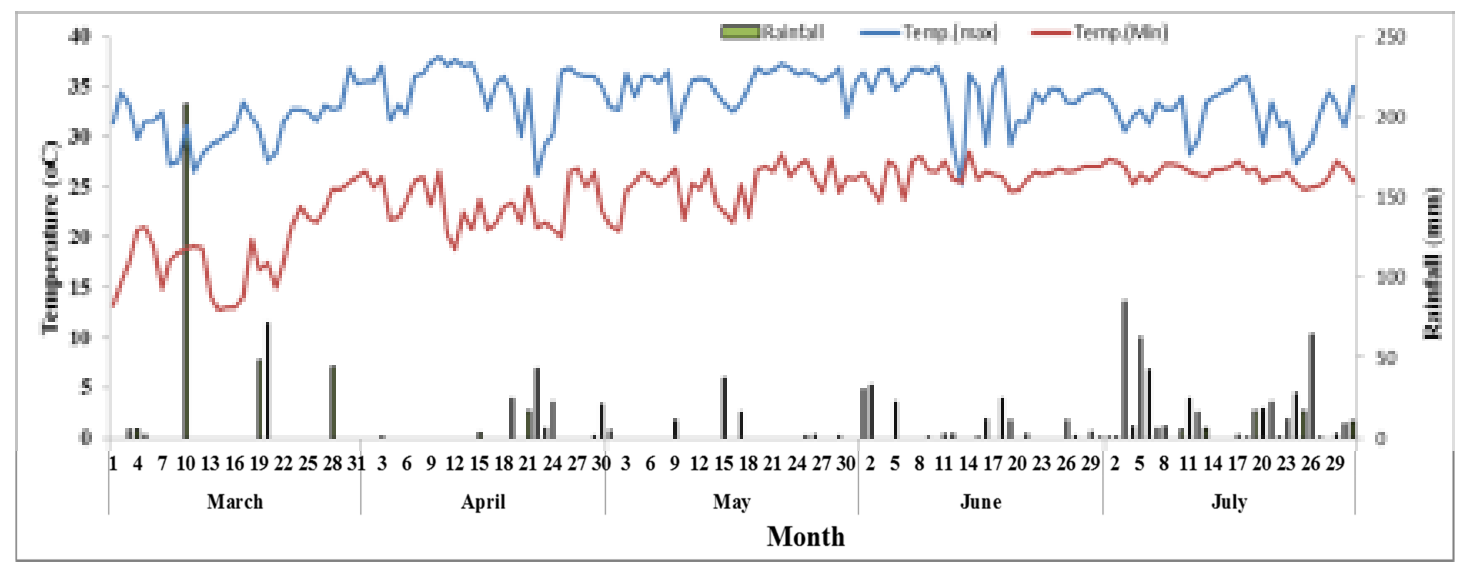

Fig. 1. Daily maximum, minimum temperature and rainfall during the cropping season 2016 at Ishurdi. 


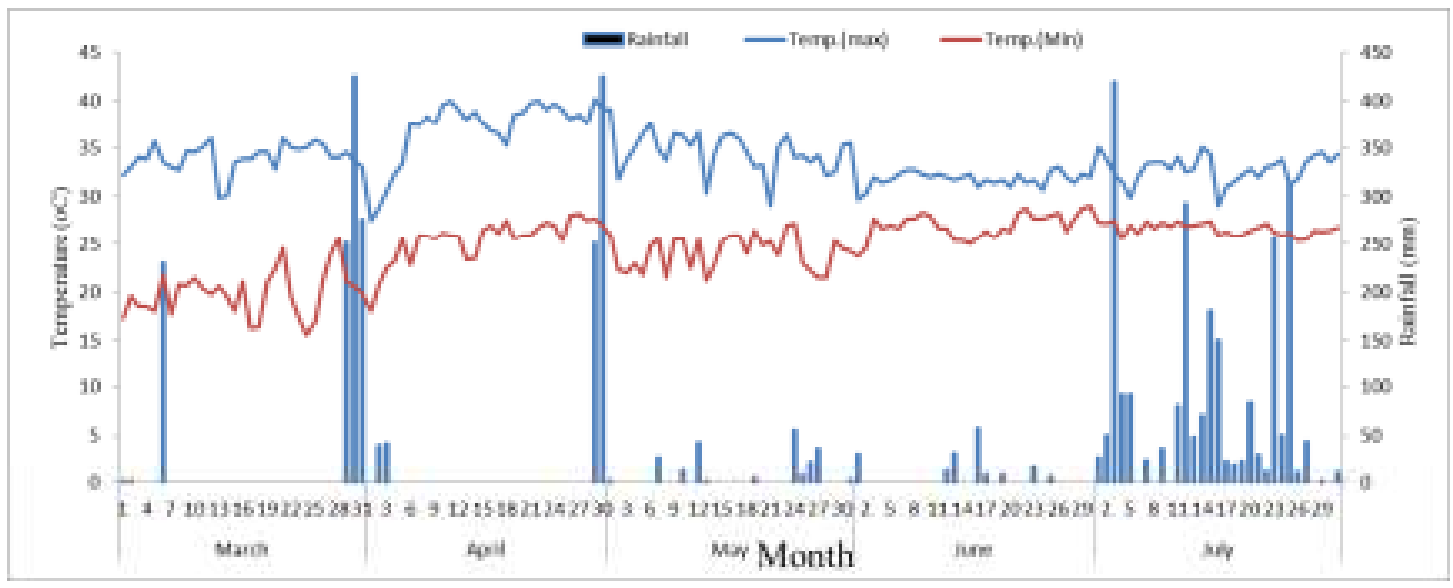

Fig. 2. Daily maximum, minimum temperature and rainfall during the cropping season 2017 at Ishurdi.

\section{Results and Discussion}

\section{Weed indices}

The number of weed species and relative weed density was affected by different weed control methods at $30 \mathrm{DAE}$ (Table 1). It was observed that Cyperus rotundus (Mutha), Digitaria sangunalis (Anguli), Cynodon dactylon (Durba) and Enhydra fluctuans (Helancha) were the common weeds in sesame field. Among the weed species, Cyperus rotundus and Digitaria sangunalis were the most dominant weeds. Khan et al. (2011) also reported that these weeds were grown abundantly in kharif-1 season in North-west region in Bangladesh. The highest number of weeds (167 m-2 in 2015-16 and $355 \mathrm{~m}^{-2}$ in 2016-17) were recorded from control treatment $\left(T_{5}\right)$ and the lowest $\left(67 \mathrm{~m}^{-2}\right.$ in 2015-16 and $115 \mathrm{~m}^{-2}$ in 2016-17) from application of Panida with one hand weeding at $20 \mathrm{DAE}\left(\mathrm{T}_{2}\right)$, which was statistically similar with $\mathrm{T}_{1}$. Application of Panida and hand weeding controlled Digitaria sangunalis and other grass weeds and controlled less of Cyperus rotundus and broad-leaf weeds, which reduced the density of grass weed than sedge and broad-leaf weeds. The weed density was higher in second growing period (2016-17) than first growing period (2015-16). This might be due to higher minimum and maximum temperatures and total rainfall in the second growing season than the first growing season.

Weed biomass was significantly influenced by different weed control methods (Table 2). The highest weed biomass $\left(155 \mathrm{~g} \mathrm{~m}^{-2}\right.$ and $\left.172 \mathrm{~g} \mathrm{~m}^{-2}\right)$ was obtained from untreated control $\left(\mathrm{T}_{5}\right)$ in 2015-16 and 2016-17, respectively and the lowest dry weight (24 g m $\mathrm{g}^{-2}$ and $25 \mathrm{~g} \mathrm{~m}^{-2}$ ) was calculated from $\mathrm{T}_{2}$ in 2015-16 and 2016-17, respectively. The weed control efficiency among the weed control methods ranged from 76 to $85 \%$ in $2015-16$ and 72 to $85 \%$ in 2016-17 (Table 2). The highest weed control efficiency was found in application of herbicide with hand weeding at $20 \mathrm{DAE}\left(\mathrm{T}_{2}\right)$, which was $85 \%$ in both years. Weed persistence index (WPI) was also varied from 0.45 to 0.38 in 2015-16 and from 0.82 to 44 in 2016-17; where application of herbicide with one hand weeding at $20 \mathrm{DAE}\left(\mathrm{T}_{2}\right)$ gave less WPI in both years. This may be attributed to better control of weeds due to suppress of weed emergence through herbicide and weeding under critical period of weed competition critical which might had provided higher weed control efficiency. The results corroborate the findings of Rahman et al. (2017), who stated that 
pre-emergence of herbicide with one weeding at 20 DAE provides less weed infestation, weed biomass and high weed control efficiency in sesame.

Table 1. Effect of weed control methods on different weed species' population and their relative weed density in sesame field at Ishurdi during 2015-16 and 2016-17

\begin{tabular}{|c|c|c|c|c|c|c|c|}
\hline \multirow[t]{2}{*}{ Treatments } & \multirow[t]{2}{*}{ Local name } & \multirow{2}{*}{$\begin{array}{l}\text { Scientific } \\
\text { name }\end{array}$} & \multirow[t]{2}{*}{ Type } & \multicolumn{2}{|c|}{$2015-16$} & \multicolumn{2}{|c|}{$2016-17$} \\
\hline & & & & $\begin{array}{c}\text { Weed } \\
\text { density } \\
\text { (no. } \mathrm{m}^{-2} \text { ) }\end{array}$ & $\begin{array}{c}\text { Relative } \\
\text { weed } \\
\text { density } \\
(\%)\end{array}$ & $\begin{array}{c}\text { Weed } \\
\text { density } \\
\left(\text { no. } \mathrm{m}^{-2}\right)\end{array}$ & $\begin{array}{c}\text { Relative } \\
\text { weed } \\
\text { density } \\
(\%)\end{array}$ \\
\hline \multirow[t]{6}{*}{$\mathrm{T}_{1}$} & Mutha & $\begin{array}{l}\text { Cyperus } \\
\text { rotundus }\end{array}$ & Sedge & 33 & 49 & 123 & 99 \\
\hline & Anguli/Khuda & Digitaria & & & & & \\
\hline & Anguli & $\begin{array}{l}\text { sangunalis/ } \\
\text { Digitaria } \\
\text { ischaemum }\end{array}$ & Grass & 19 & 28 & 1 & 1 \\
\hline & Others & & Broadleaf & 10 & 15 & 0 & 0 \\
\hline & Durba & $\begin{array}{l}\text { Cynodon } \\
\text { dactylon }\end{array}$ & & 6 & 9 & 0 & 0 \\
\hline & Total & & & 68 & 100 & 124 & 100 \\
\hline \multirow[t]{6}{*}{$\mathrm{T}_{2}$} & Mutha & $\begin{array}{l}\text { Cyperus } \\
\text { rotundus }\end{array}$ & Sedge & 40 & 60 & 114 & 99 \\
\hline & Anguli & Digitaria $s p$. & Grass & 18 & 27 & 1 & 1 \\
\hline & Helancha & $\begin{array}{l}\text { Enhydra } \\
\text { fluctuans }\end{array}$ & Broadleaf & 2 & 3 & 0 & 0 \\
\hline & Durba & $\begin{array}{l}\text { Cynodon } \\
\text { dactylon }\end{array}$ & & 4 & 6 & 0 & 0 \\
\hline & Other & & & 3 & 4 & 0 & 0 \\
\hline & Total & & & 67 & 100 & 115 & 100 \\
\hline \multirow[t]{3}{*}{$\mathrm{T}_{3}$} & Mutha & $\begin{array}{l}\text { Cyperus } \\
\text { rotundus }\end{array}$ & Sedge & 36 & 41 & 155 & 80 \\
\hline & Anguli & Digitaria $s p$. & Grass & 52 & 59 & 38 & 20 \\
\hline & Total & & & 88 & 100 & 193 & 100 \\
\hline \multirow[t]{3}{*}{$\mathrm{T}_{4}$} & Mutha & $\begin{array}{l}\text { Cyperus } \\
\text { rotundus }\end{array}$ & Sedge & 39 & 45 & 165 & 86 \\
\hline & Anguli & Digitaria $s p$. & Grass & 47 & 55 & 37 & 19 \\
\hline & Total & & & 86 & 100 & 192 & 100 \\
\hline \multirow[t]{3}{*}{$\mathrm{T}_{5}$} & Mutha & $\begin{array}{l}\text { Cyperus } \\
\text { rotundus }\end{array}$ & Sedge & 81 & 49 & 260 & 73 \\
\hline & Anguli & Digitaria $s p$. & Grass & 86 & 51 & 95 & 27 \\
\hline & Total & & & 167 & 100 & 355 & 100 \\
\hline $\operatorname{LSD}_{(0.05 \%)}$ & & - & - & 9.74 & - & 10.31 & - \\
\hline CV (\%) & & - & - & 5.43 & - & 2.79 & - \\
\hline
\end{tabular}

$\mathrm{T}_{1}$ : Application of Panida; $\mathrm{T}_{2}$ : Application of Panida with one hand weeding at $20 \mathrm{DAE} ; \mathrm{T}_{3}$ : One hand weeding at $20 \mathrm{DAE} ; \mathrm{T}_{4}$ : Two hand weeding at 20 and $40 \mathrm{DAE} ; \mathrm{T}_{5}$ : Control (unweeded). 
Table 2. Weed biomass, weed control efficiency and weed persistence index of sesame in different weed control methods at Ishurdi during 2015-16 and 2016-17

\begin{tabular}{|c|c|c|c|c|c|c|}
\hline \multirow[t]{2}{*}{ Treatments } & \multicolumn{2}{|c|}{$\begin{array}{l}\text { Weed biomass } \\
\qquad\left(\mathrm{g} \mathrm{m}^{-2}\right)\end{array}$} & \multicolumn{2}{|c|}{ Weed control efficiency (\%) } & \multicolumn{2}{|c|}{ Weed persistence index } \\
\hline & $2015-16$ & 2016-17 & 2015-16 & 2016-17 & 2015-16 & 2016-17 \\
\hline $\mathrm{T}_{1}$ & 37 & 49 & 76 & 72 & 0.58 & 0.82 \\
\hline $\mathrm{T}_{2}$ & 24 & 25 & 85 & 85 & 0.38 & 0.45 \\
\hline $\mathrm{T}_{3}$ & $31 b$ & 44 & 80 & 74 & 0.38 & 0.47 \\
\hline $\mathrm{T}_{4}$ & 33 & 41 & 79 & 76 & 0.41 & 0.44 \\
\hline $\mathrm{T}_{5}$ & 155 & 172 & - & - & - & - \\
\hline $\operatorname{LSD}_{(0.05 \%)}$ & 9.02 & 5.25 & - & - & - & - \\
\hline CV (\%) & 8.53 & 4.20 & - & - & - & - \\
\hline
\end{tabular}

$\mathrm{T}_{1}$ : Application of Panida; $\mathrm{T}_{2}$ : Application of Panida with one hand weeding at $20 \mathrm{DAE} ; \mathrm{T}_{3}$ : One hand weeding at $20 \mathrm{DAE} ; \mathrm{T}_{4}$ : Two hand weeding at 20 and $40 \mathrm{DAE} ; \mathrm{T}_{5}$ : Control (unweeded).

\section{Yield components and yield of sesame}

Plant population had no significant difference among different weed control methods (Table 3). Plant population varied 28-32 $\mathrm{m}^{-2}$. However, higher plant population was found under application of Panida with hand weeding at $20 \mathrm{DAE}$, while lower plant population in weedy check. Hossain et al. (2010) also found similar results. The plant height was affected significantly by the treatments (Table 3). The maximum plant height was found in application of herbicide with one hand weeding at $20 \mathrm{DAE}(124 \mathrm{~cm})$, which was statistically similar at application of Panida $\left(\mathrm{T}_{1}\right)$ and one hand weeding at $20 \mathrm{DAE}\left(\mathrm{T}_{3}\right)$. The lowest plant height was recorded in untreated plot $(110 \mathrm{~cm})$. The plant height was increased in better weed control management at proper time possibly due to consume of maximum utilization of moisture and nutrients by crop (Riaz et al., 2006). The number of branches plant ${ }^{-1}$ had not significant effect among the treatments, which ranged 2.87-1.97. Application of herbicide with one hand weeding at 20 DAE $\left(\mathrm{T}_{2}\right)$ gave the maximum number of capsule per plant (45) which was statistically at par to $T_{1}$. The lowest number of capsule per plant (37) recorded in $T_{5}$ and $T_{5}$. The results were in agreement with the findings of Ambika and Sundari (2019) that pre-emergence herbicide treatment along with one hand weeding resulted in maximum number of capsules plant ${ }^{-1}$ of sesame. Capsule length and seeds capsule $e^{-1}$ had no significant effect among the treatments. Capsule length ranged $1.97-1.73 \mathrm{~cm}$ and number of seeds capsule ${ }^{-1}$ varied $77-70$. The highest thousand seed weight was recorded from $T_{2}$, which was statistically similar to treatment $T_{1}$ and $T_{3}$, and the lowest thousand seed was calculated in $T_{5}$. Similar results have also been reported by Akter (2015), who mentioned that 1000-seed weight was higher when two hand weeding was done or herbicide applied at pre-emergence condition. The seed yield of sesame was significantly influenced by different weed management methods (Table 4.). Higher seed yield $\left(805 \mathrm{~kg} \mathrm{ha}^{-1}\right)$ was obtained from $\mathrm{T}_{1}$ followed by $\mathrm{T}_{2}$ treatment and lower seed yield was gained at $T_{5}$. Seed yield was increased $130 \%$ in $T_{2}$ over control which was followed by $T_{1}$. The improvement in seed yield under these treatments may be attributed to more weed reduction at critical growth stages of crop which favored healthy plant growth to produce maximum number of capsule plant ${ }^{-1}$ and thousand seed weight which gave higher yield of sesame. The results were in agreement with the findings of Rahaman et al. (2017) that pre-emergence herbicide treatment along with one hand weeding resulted in maximum seed yield of sesame. But Hossain et al. (2020) reported that two hand weedings at 15 and 30 DAS gave higher seed yield in sesame. 
Application of Panida with one hand weeding at $20 \mathrm{DAE}\left(\mathrm{T}_{2}\right)$ and application of Panida $\left(\mathrm{T}_{1}\right)$ also gave the highest stalk yield (3361 kg ha ${ }^{-1}, 3167 \mathrm{~kg} \mathrm{ha}^{-1}$ respectively). Unweeded treatment $\left(\mathrm{T}_{5}\right)$ recorded the lowest stalk yield $\left(1180 \mathrm{~kg} \mathrm{ha}^{-1}\right)$ due to severe weed competition with sesame which resulted in stunted growth and lower yield. This is in agreement with the findings of Mruthul et al. (2015).

Table 3. Yield contributing characters of sesame as affected by different weed control methods at Ishurdi during 2015-16 and 2016-17 (Pooled)

\begin{tabular}{lccccc}
\hline Treatments & $\begin{array}{c}\text { Plant population } \\
\mathbf{m}^{-2}\end{array}$ & $\begin{array}{c}\text { Plant height } \\
\text { (cm) }\end{array}$ & $\begin{array}{c}\text { Branches } \\
\text { plant }^{-1} \text { (no.) }\end{array}$ & $\begin{array}{c}\text { Capsules } \\
\text { plant }^{-1} \text { (no.) }\end{array}$ & $\begin{array}{c}\text { Capsule } \\
\text { length (cm) }\end{array}$ \\
\hline $\mathrm{T}_{1}$ & 31 & 123 & 2.87 & 43 & 1.97 \\
$\mathrm{~T}_{2}$ & 32 & 124 & 2.63 & 45 & 1.87 \\
$\mathrm{~T}_{3}$ & 30 & 119 & 1.97 & 38 & 1.75 \\
$\mathrm{~T}_{4}$ & 30 & 117 & 2.07 & 37 & 1.80 \\
$\mathrm{~T}_{5}$ & 28 & 110 & 2.40 & 37 & 1.73 \\
\hline $\mathrm{LSD}_{(0.05)}$ & $\mathrm{NS}$ & 4.66 & $\mathrm{NS}$ & 4.57 & $\mathrm{NS}$ \\
$\mathrm{CV}(\%)$ & 11.16 & 3.21 & 5.11 & 9.29 & 12.48 \\
\hline
\end{tabular}

$\mathrm{T}_{1}$ : Application of Panida; $\mathrm{T}_{2}$ : Application of Panida with one hand weeding at $20 \mathrm{DAE} ; \mathrm{T}_{3}$ : One hand weeding at $20 \mathrm{DAE} ; \mathrm{T}_{4}$ : Two hand weeding at 20 and $40 \mathrm{DAE} ; \mathrm{T}_{5}$ : Control (unweeded); $\mathrm{CV}=$ Coefficient of Variation

Table 4. Yield and yield contributing characters of sesame as affected by different weed control methods at Ishurdi during 2015-16 and 2016-17 (Pooled)

\begin{tabular}{lccccc}
\hline Treatment & $\begin{array}{c}\text { Seeds } \\
\text { capsule } \\
\text { (no.) }\end{array}$ & $\begin{array}{c}\text { 1000-seed } \\
\text { weight (g) }\end{array}$ & $\begin{array}{c}\text { Seed yield } \\
\text { (Kg ha-1) }\end{array}$ & $\begin{array}{c}\text { Stalk yield } \\
\left(\mathrm{Kg} \mathrm{ha}^{-1}\right)\end{array}$ & $\begin{array}{c}\text { Seed yield } \\
\text { increase over } \\
\text { control (\%) }\end{array}$ \\
\hline $\mathrm{T}_{1}$ & 74 & 1.76 & 771 & 3167 & 120 \\
$\mathrm{~T}_{2}$ & 77 & 1.91 & 805 & 3361 & 130 \\
$\mathrm{~T}_{3}$ & 73 & 1.74 & 524 & 1583 & 50 \\
$\mathrm{~T}_{4}$ & 70 & 1.69 & 514 & 1972 & 47 \\
$\mathrm{~T}_{5}$ & 71 & 1.49 & 350 & 1180 & 0 \\
\hline $\mathrm{LSD}_{(0.05 \%)}$ & $\mathrm{NS}$ & 0.17 & 43.56 & 195 & - \\
$\mathrm{CV}(\%)$ & 8.54 & 8.23 & 6.00 & 7.07 & - \\
\hline
\end{tabular}

$\mathrm{T}_{1}$ : Application of Panida; $\mathrm{T}_{2}$ : Application of Panida with one hand weeding at $20 \mathrm{DAE} ; \mathrm{T}_{3}$ : One hand weeding at $20 \mathrm{DAE} ; \mathrm{T}_{4}$ : Two hand weeding at 20 and $40 \mathrm{DAE} ; \mathrm{T}_{5}$ : Control (unweeded); $\mathrm{CV}=$ Coefficient of Variation.

According to regression analysis of the obtained results, plant height, number of capsule plant ${ }^{-1}$, seed yield and stalk yield were changed to various weed biomass under different treatments (Fig. 3). Weed biomass accounted for $75 \%$ variations in plant height, $23 \%$ variations in capsule plant ${ }^{-}$ $1,52 \%$ variations in seed yield and 39\% variations in stalk yield, which could result to the competition for growth resources between weeds and crop. The association analysis was also performed using two years mean data among weed biomass and yield attributing traits, and the 
results revealed that weed biomass showed a negative correlation with plant height $(r=-0.87)$, number of capsule plant ${ }^{-1}(r=-0.48)$, seed yield $(r=-0.73)$ and stalk yield $(r=-0.63)$. These results are agreement with the findings of Aktar et al. (2013), who stated that increasing trend of weed biomass decreases the yield of the crop.
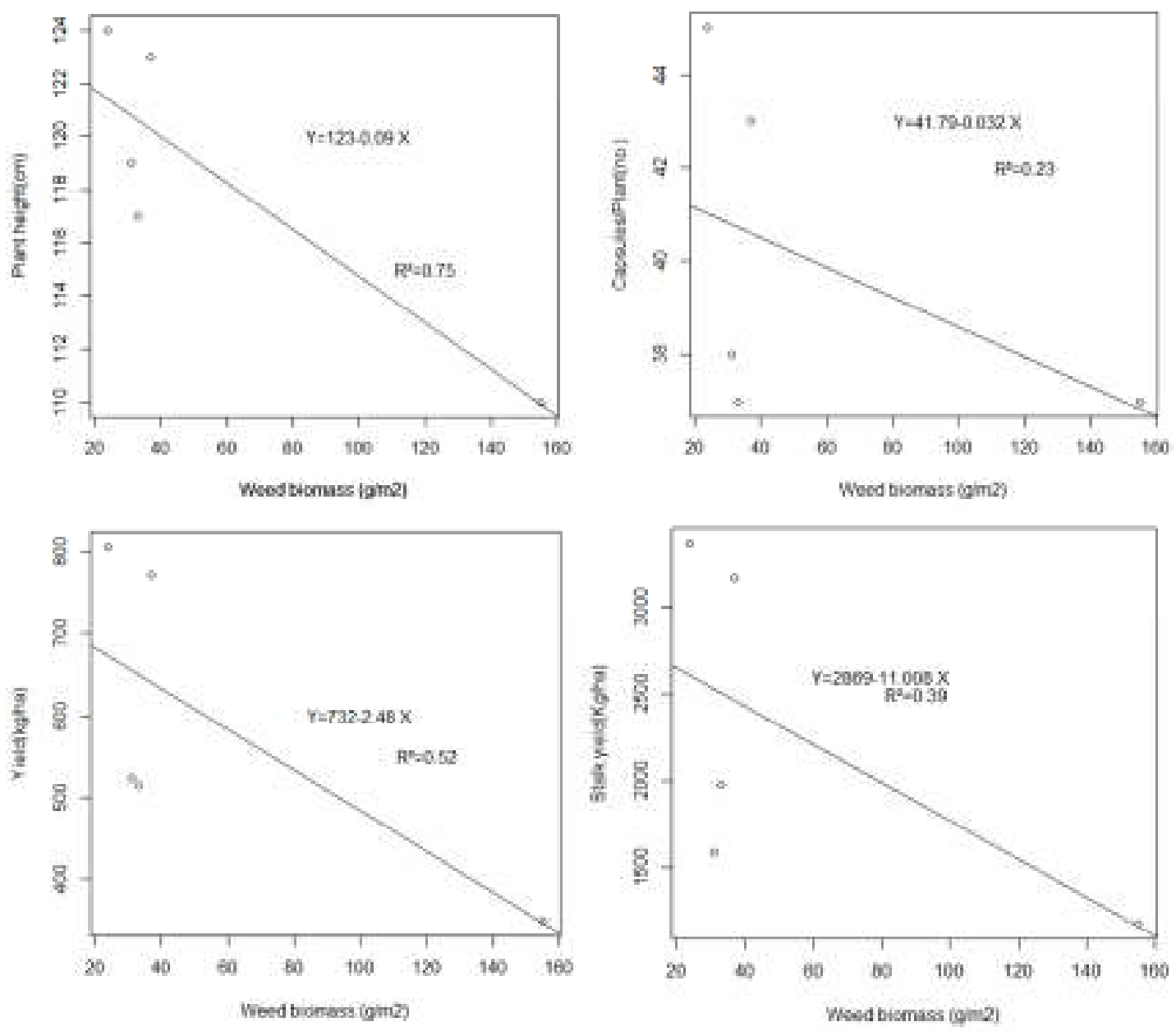

Fig. 3. Plant height, capsule plant ${ }^{-1}$, seed yield and stalk yield depended on the weed biomass under different weed control methods.

\section{Economics}

Economic analysis of different weed control methods on sesame has shown in Table 5 . The highest gross return (Tk. $56350 \mathrm{ha}^{-1}$ ) was registered with application of Panida with one hand weeding at 20 DAE followed by application of Panida and the least gross return was registered in unweeded control (Tk. $24500 \mathrm{ha}^{-1}$ ). But two hand weeding at $20 \mathrm{DAE}$ and $40 \mathrm{DAE}$ attributed the highest cost (Tk. $\left.42750 \mathrm{ha}^{-1}\right)$ and less cost in (Tk. $\left.18750 \mathrm{ha}^{-1}\right)$ in control (T5). The highest gross margin (Tk. $33189 \mathrm{ha}^{-1}$ ) and BCR (2.60) were obtained from pre-emergence of Panida followed by pre-emergence of Panida with one hand weeding at $20 \mathrm{DAE}$. This might be due to high cost of labour for hand weeding resulting in the increase of variable cost and reducing the 
marginal return, which affect the benefit cost ratio. These findings are supported by other workers (Rahman et al., 2017; Ambika and Sundari, 2019).

Table 5. Economic performance of sesame under different weed control methods

\begin{tabular}{lcccc}
\hline Treatments & $\begin{array}{c}\text { Gross return } \\
(\text { Tk. ha }\end{array}$ ) & $\begin{array}{c}\text { Total variable } \\
\text { cost }\left(\text { Tk. ha }^{-1}\right)\end{array}$ & $\begin{array}{c}\text { Gross margin } \\
\left(\text { Tk. ha }^{-1}\right)\end{array}$ & BCR \\
\hline $\begin{array}{l}\text { Application of Panida } \\
\text { Application of Panida with one hand }\end{array}$ & 53970 & 20781 & 33189 & 2.60 \\
weeding at 20 DAE & 56350 & 32781 & 23569 & 1.72 \\
$\begin{array}{l}\text { One hand weeding at 20 DAE } \\
\text { Two hand weeding at 20 and 40 }\end{array}$ & 36680 & 30750 & 5930 & 1.19 \\
DAE & 35980 & 42750 & -6770 & 0.84 \\
Control & 24500 & 18750 & 5750 & 1.31 \\
\hline
\end{tabular}

Cost:- Sesame : Tk.70 kg-1, Panida 33 EC: Tk. 325 per 400 mL, Urea: Tk. 16 Kg-1, TSP: Tk. 22 Kg-1, MoP: Tk. $15 \mathrm{Kg}^{-1}$, Labour : Tk. 400 eight hour ${ }^{-1}$ head $^{-1}$

\section{Conclusion}

Application of herbicide, Panida 33 EC in pre-emergence condition with one hand weeding at 20 days after emergence decreased the weed infestation and weeds biomass, and increased the weed control efficiency, which was followed by the application of Panida 33 EC in preemergence. Although, the treatment of application of Panida $33 \mathrm{EC}$ in pre-emergence condition with one hand weeding at 20 days after emergence gave the highest seed yield, on the basis of economic point of view application of Panida 33 EC in pre-emergence condition was profitable and suitable weed control method in summer sown sesame.

\section{References}

Ambika, M. and A. Sundari. 2019. Weed management in irrigated sesame (Sesamum indicum L.). World Scient. News. 131: 272-278.

Aktar, N. 2015. Weed management towards improvement of growth and yield of sesame varieties. M. S. Thesis, Dept. of Agronomy. Sher-E-Bangla Agricultural University, Dhaka. p.53.

Aktar, S., M.A. Hossain, A. Siddika, N. Naher, and M.R. Amin. 2013. Efficacy of herbicides on the yield of lentil (Lens culinaris Medik.). The Agriculturists. 11(1): 89-94.

Amare, M. 2011. Estimation of critical period for weed control in sesame (Sesamum indicum L.) in northern Ethiopia. Ethiopia J. Appl. Sci. Technol. 2(1): 59-66.

BBS (Bangladesh Bureau of Statistics). 2019. Yearbook of Agricultural Statistics-2018. Bangladesh Bureau of Statistics, Ministry of Planning, Government of the Peoples Republic of Bangladesh. p.40.

FRG. 2012. Fertilizer recommendation guide, Bangladesh Agricultural Research Council (BARC), Farmgate, Dhaka 121. p.274.

Gomez K.A. and A.A. Gomez. 1984. Statistical Procedures for Agricultural Research. John Willey and Sons, New York, USA. 
Hossain, M.S., A. Rahman. M. Salim, M. Hoque and A.K. Hasan. 2020. Response of selected sesame varieties to different weed management practices. Fund. Appl. Agril. 5(2): 167-175. doi:10.5455/faa.80257.

Hossain, A., M.A.S. Chowdhury, P.K. Malaker, M.S.N. Mandal and M.A.Z. Sarker. 2010. Efficacy and economics of herbicides against narrow and broad-leaved weeds of wheat. Bangladesh $\mathrm{J}$. Weed Sci. 1(1): 71-79.

Jain, V.K., Y.S. Chauhan and M.K. Bhargava. 2001. Chemical weed control in soybean (Glycine $\max$ (L.) Merrill.). Pestol. 25(10): 11-14.

Jain, N. and A.J. Badkul. 2013. Herbicidal weed control in Sesame (Sesamum indicum L.). J. Pharma. Phytochem. 2(1): 349-352.

Khan, M.S.A., M.T. Rahman, S.N. Mahfuza, S. Akther and M. Akhteruzzaman. 2011. Weed survey in mungbean field at different agro-ecological zones of Bangladesh. J. Expt. Biosci. 2(2): 3946.

Karnas, Z., D. Isik, N. Tursun and K. Jabran. 2019. Critical period for weed control in sesame production. Weed Biol. Mng. 19: 121-128.

Mruthul, T., A.S. Halepyati and B.M. Chittapur. 2015. Chemical weed management in sesame (Sesamum indicum L.). Karnataka J. Agric. Sci. 28(2): 151-154.

Mani, V.S., M.L. Pandita, K.C. Gautam and B. Wandas. 1973. Weed hilling chemicals in potato cultivation. PANS. 23: 17-18.

Misra, M. and A. Misra. 1997. Estimation of IPM index in Jute: a new approach. Indian J. Weed Sci. 29: 39-42.

Odum, E.P. 1971. Fundamentals of Ecology. W. B. Saunders Company, Philadelphia. 574p.

Punia, S.S., M. Raj, Y. Ashok and R.K. Malik. 2001. Bioefficacy of dinitroaniline herbicides against weeds in sesame. Indian J. Weed Sci. 33(3, 4): 143-143.

R Core Team. 2016. R: A language and environment for statistical computing. $\mathrm{R}$ foundation for statistical computing, Vienna, Austria. URL https://www.R-project.org/.

Riaz, M., M.A. Malik, T.Z. Mahmood and M. Jamil. 2006. Effect of various weed control methods on yield and yield components of wheat under different cropping patterns. Int. J. Agric. Bio. 8(5): 636-640.

Rahman, J., M.I. Riad, F.S. Shikha, R. Sultana and N. Akter. 2017. Weed control methods in sesame. Int. J. Agron. Agri. Res. 11(5): 1-6. 